\title{
ESTIMATION OF CAFFEINE INTAKE FROM ANALYSIS OF CAFFEINE METABOLITES IN WASTEWATER
}

Emma Gracia-Lor ${ }^{\mathrm{a}, \mathrm{b}^{*}}$, Nikolaos I. Rousis ${ }^{\mathrm{a}}$, Ettore Zuccato ${ }^{\mathrm{a}}$, Richard Bade ${ }^{\mathrm{b}, \mathrm{c}}$, Jose Antonio Baz-Lomba $^{\mathrm{d}, \mathrm{e}}$, Erika Castrignanò ${ }^{\mathrm{f}}$, Ana Causanilles ${ }^{\mathrm{g}}$, Félix Hernández ${ }^{\mathrm{b}}$, Barbara KasprzykHordern $^{\mathrm{f}}$, Juliet Kinyua ${ }^{\mathrm{h}}$, Ann-Kathrin McCall ${ }^{\mathrm{i}}$, Alexander L.N. van Nuijs ${ }^{\mathrm{h}}$, Benedek G. Plósz ${ }^{\mathrm{j}, \mathrm{k}}$, Pedram Ramin ${ }^{\mathrm{j}, \mathrm{l}}$, Yeonsuk Ryu ${ }^{\mathrm{d}, \mathrm{e}}$, Miguel M. Santos ${ }^{\mathrm{m}, \mathrm{n}}$, Kevin Thomas ${ }^{\mathrm{d}, \mathrm{o}}$, Pim de Voogt $^{\mathrm{g}, \mathrm{p}}$, Zhugen Yang $^{\mathrm{f}, \mathrm{q}}$ and Sara Castiglioni ${ }^{\mathrm{a} *}$

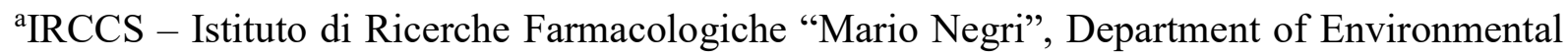
Health Sciences, Via La Masa 19, 20156, Milan, Italy

${ }^{b}$ Research Institute for Pesticides and Water, University Jaume I, Avda. Sos Baynat s/n, E12071, Castellon, Spain

${ }^{\mathrm{c} S c h o o l}$ of Pharmacy and Medical Sciences, University of South Australia, Adelaide, South Australia 5000, Australia

${ }^{\mathrm{d}}$ Norwegian Institute for Water Research (NIVA), Gaustadalléen 21, 0349 Oslo, Norway

${ }^{\mathrm{e}}$ Faculty of Medicine, University of Oslo, PO box 1078 Blindern, 0316, Oslo, Norway

fUniversity of Bath, Department of Chemistry, Faculty of Science, Bath BA2 7AY, United Kingdom

gKWR Watercycle Research Institute, Chemical Water Quality and Health, P.O. Box 1072, 3430 BB, Nieuwegein, The Netherlands

${ }^{\mathrm{h}}$ Toxicological Center, Department of Pharmaceutical Sciences, Campus Drie Eiken, University of Antwerp, Universiteitsplein 1, 2610 Antwerp, Belgium 
${ }^{\mathrm{i} E a w a g, ~ S w i s s ~ F e d e r a l ~ I n s t i t u t e ~ o f ~ A q u a t i c ~ S c i e n c e ~ a n d ~ T e c h n o l o g y, ~ C H-8600, ~ D u ̈ b e n d o r f, ~}$ Switzerland

${ }^{\mathrm{j} D e p a r t m e n t}$ of Environmental Engineering, Technical University of Denmark, Bygningstorvet, Building 115, DK-2800 Kgs. Lyngby, Denmark

${ }^{\mathrm{k}}$ Department of Chemical Engineering, University of Bath, Claverton Down, Bath BA2 7AY, UK

${ }^{1}$ Department of Chemical and Biochemical Engineering, Technical University of Denmark, Søltofts Plads, Building 229, DK-2800 Kgs. Lyngby, Denmark

${ }^{\mathrm{m} C I M A R / C I I M A R-I n t e r d i s c i p l i n a r y}$ Centre of Marine and Environmental Research, University of Porto, Avenida General Norton de Matos, S/N, 4450-208 Matosinhos, Portugal ${ }^{\mathrm{n}}$ FCUP - Department of Biology, Faculty of Sciences, University of Porto, Rua do Campo Alegre, 4169-007 Porto, Portugal

${ }^{\circ}$ Queensland Alliance for Environmental Health Sciences (QAEHS), University of Queensland, 39 Kessels Road Coopers Plains, Queensland 4108 Australia

${ }^{\mathrm{p}}$ Institute for Biodiversity and Ecosystem Dynamics, University of Amsterdam, P.O. Box 94248, 1090 GE, Amsterdam, The Netherlands

${ }^{\mathrm{q}}$ Division of Biomedical Engineering, School of Engineering, University of Glasgow, Glasgow G12 8LT United Kingdom

\section{*Corresponding author:}

E-mail addresses: 1or@uji.es (E. Gracia-Lor), sara.castiglioni@marionegri.it (S. Castiglioni) 


\begin{abstract}
Caffeine metabolites in wastewater were investigated as potential biomarkers for assessing caffeine intake in a population. The main human urinary metabolites of caffeine were measured in the urban wastewater of ten European cities and the metabolic profiles in wastewater were compared with the human urinary excretion profile. A good match was found for 1,7-dimethyluric acid, an exclusive caffeine metabolite, suggesting that might be a suitable biomarker in wastewater for assessing population-level caffeine consumption. A correction factor was developed considering the percentage of excretion of this metabolite in humans, according to published pharmacokinetic studies. Daily caffeine intake estimated from wastewater analysis was compared with the average daily intake calculated from the average amount of coffee consumed by country per capita. Good agreement was found in some cities but further information is needed to standardize this approach. Wastewater analysis proved useful to providing additional local information on caffeine use.
\end{abstract}

Key words: Caffeine; 1,7-dimethyluric acid; back-calculation; correction factor; wastewaterbased epidemiology; urinary biomarkers 


\section{INTRODUCTION}

History suggests that caffeine has been used, in one form or another, since ancient times. In $2737 \mathrm{BC}$ a Chinese Emperor used the leaves from a nearby bush to prepare a tea (Arab and Blumberg, 2008; Heckman et al., 2010). An old legend dates the use of coffee to the 9th century in the southern tip of the Arabian Peninsula when a shepherd noted euphoria and stimulating effects on his goats caused by eating wild coffee berries. He then decided to try them himself. Coffee later crossed to Africa and in the 1600s reached Europe becoming, over the centuries, the most commonly consumed beverage worldwide after water (Butt and Tauseef, 2011).

Caffeine is a naturally occurring alkaloid found in beans, leaves and fruits of more than 60 plant species. The world's main sources are coffee beans (Coffea arabica and Coffea robusta) and tea leaves (Camellia siniensis). It is also naturally found in kola nuts (Cola acuminate), cocao beans (Theobroma cacao), yerba mate (Ilex paraguariensis) and guarana berries (Paullinia cupana). Most caffeine is consumed with beverages such as coffee, tea and soft drinks (including "energy drinks"), while products containing cocoa or chocolate, and medications such as some analgesic formulations and dietary supplements contribute small amounts to the diet (Heckman et al., 2010). Total daily intakes vary throughout the world although coffee usually contributes significantly more than other drinks to overall caffeine consumption (coffee $71 \%$, soft drinks $16 \%$ and tea $12 \%$ ), particularly among adults (Heckman et al., 2010; Mitchell et al., 2014). Carbonated Soft drinks are the main source of caffeine for children (Mitchell et al., 2014).

Chocolate contains on average around $1.3 \%$ of theobromine, $0.75 \%$ of caffeine and theophylline in small amounts; cola nut between 2 and $3.5 \%$ of caffeine, theobromine (between 1 and 3.5\%) and small amounts of theophylline, and tea leaves around 3\% of 
caffeine (theophylline and theobromine in small amounts). This results in around 40-80 $\mathrm{mg}$ of caffeine per cup of tea $(150 \mathrm{~mL})$ while caffeine content in cocoa commercial products ranges from 2 to $7 \mathrm{mg}$ (Barone and Roberts, 1996) and 5-20 mg/100 g in chocolate candy products. In soft drinks, variable levels of caffeine have been reported depending on the brand but the typical content is around $40 \mathrm{mg} / 360 \mathrm{~mL}$ (Chou and Bell, 2007). All these products contain relatively little caffeine compared to the average content of a coffee cup $(60-150 \mathrm{mg} / 150 \mathrm{~mL})$.

Caffeine is extensively metabolized by the human liver to form three major metabolites by demethylation: 3,7-dimethylxanthine (known as theobromine), 1,7dimethylxanthine (paraxanthine) and 1,3-dimethylxanthine (theophylline). These are then broken down further in the liver by additional demethylation and oxidation and are excreted mostly in the urine (Heckman et al., 2010).

While there is no specific recommendation for human caffeine intake, it is considered that average consumption of approximately $300 \mathrm{mg} /$ day is not associated with adverse health effects (Fitt et al., 2013; Higdon and Frei, 2006). However, data about caffeine intake in the population are scarce. Caffeine consumption is usually assessed by dietary surveys, but getting accurate information in this way presents many limitations. For instance, subjects may under-report their caffeine intake when food diaries are completed or information is missing about the strength, brand or amount of caffeine product they have consumed, which may greatly affect the intake. Another limitation is that in caffeine dietary surveys the subjects are usually asked about the consumption of certain beverages (mainly coffee and tea) but other products containing caffeine are not considered: for example, analgesics can contain as much as $200 \mathrm{mg}$ caffeine per tablet (Derbyshire and Abdula, 2008). Another limitation for estimating the total caffeine intake is that the caffeine content of various drinks, food and dietary supplements is only known in some countries such as the USA (Fitt et al., 2013). 
A complementary method would be to estimate consumption in the general population by using the levels of caffeine and its metabolites measured in urban wastewater as biomarkers of intake. This approach, called wastewater-based epidemiology (WBE), has been mainly applied in the last decade for estimating illicit drug consumption (Baker et al., 2014; Ort et al., 2014; Thomas et al., 2012; Zuccato et al., 2008) and more recently has also been proposed for the quantitative measurement of lifestyle habits such as tobacco and alcohol use, exposure to environmental and food contaminants or factors related to health and illness in a community (Lopes et al., 2014; Reid et al., 2011; Rodríguez-Álvarez et al., 2015; Rousis et al., 2017; Thomas and Reid, 2011; Yang et al., 2015). The main advantage of WBE is that it provides objective, up-to-date information about the use of these substances in a population and can therefore complement current epidemiological methods.

In this study, the presence of caffeine and some selected metabolites was assessed in untreated wastewater in ten European cities. Levels in wastewater were compared with those measured in urine and with the human excretion profiles of caffeine reported in the literature in order to correlate the results from the different sources. 1,7-dimethyluric acid, an exclusive caffeine metabolite, was selected for estimating collective caffeine consumption. The reliability of this compound for caffeine back-calculation was evaluated by comparing the amounts measured by wastewater analysis with the average amount of coffee consumed in each country per capita.

\section{MATERIALS AND METHODS}

\subsection{Chemicals and reagents}

Caffeine (1,3,7-trimethlxanthine), paraxanthine and 1-methylxanthine were purchased from Sigma Aldrich (St. Louis, MO, USA); 1-methyluric acid, 1,7-dimethyluric acid 7methylxanthine were purchased from Santa Cruz Biotechnology, Inc (Santa Cruz, California, 
USA). Standard solutions at $1 \mathrm{mg} / \mathrm{mL}$ were prepared in methanol, except for 1methylxanthine, 7-methylxanthine, paraxanthine and 1,7-dimethyluric acid which were prepared in methanol-water (50/50) at $\mathrm{pH} 8.5-10$ (adjusted with $25 \%$ ammonia to enhance solubility). A mix of all compounds at $10 \mathrm{ng} / \mu \mathrm{L}$ was prepared in methanol and then diluted to $1.0,0.1$ and $0.01 \mathrm{ng} / \mu \mathrm{L}$. Isotopically labeled compounds were caffeine- ${ }^{13} \mathrm{C}_{3}$ purchased from Sigma Aldrich and 1,7-dimethyluric acid-d $\mathrm{d}_{3}$ from Santa Cruz Biotechnology. Labeled internal solutions were prepared separately. Internal standard mixtures with $1 \mathrm{ng} / \mu \mathrm{L}$ of caffeine- ${ }^{13} \mathrm{C}_{3}$ and $10 \mathrm{ng} / \mu \mathrm{L}$ of 1,7 -dimethyluric acid- $\mathrm{d}_{3}$ were used as surrogates.

All solvents were of reagent grade or higher. Methanol for pesticide analysis and ammonium acetate were from Carlo Erba Reagents (Italy). Ammonium hydroxide solution (25\%) was acquired from Fluka (Buchs, Switzerland). LC-MS grade acetonitrile and hydrochloric acid (37\%) were supplied by Riedel de Haen (Seelze, Germany). Water was purified using Milli-RO Plus 90 apparatus (Millipore, Molsheim, France). Solid-phase cartridges $(3 \mathrm{~mL}$ Oasis HLB, $60 \mathrm{mg})$ and HPLC XTerra C18 column $(3.5 \mu \mathrm{m}, 1 \mathrm{~mm} \times 100$ mm) were obtained from Waters Corp., Milford, MA, USA.

\subsection{Wastewater samples}

24-hour composite influent wastewater samples were collected from ten wastewater treatment plants (WWTP) in different European cities: Bristol (UK), Brussels (Belgium), Castellón (Spain), Copenhagen (Denmark), Lugano (Switzerland), Milan (Italy), Oslo (Norway), Porto (Portugal), Utrecht (Netherlands) and Zurich (Switzerland) (Table S2). Samples were collected daily for seven consecutive days in March 2015 and April 2015 (Porto), frozen immediately after collection to prevent degradation of the compounds and sent to Milan within 24 hours in cooler boxes with dry ice or ice packs to keep them frozen. 
Samples were stored at $-20^{\circ} \mathrm{C}$ until analysis. For each sample the flow rate of the sewage stream (L/day) was recorded.

\subsection{Extraction and analysis}

Before solid phase extraction, samples were thawed in a warm bath, then filtered to remove suspended particulate matter through $1.6 \mu \mathrm{m}$ GF/A glass microfiber filters and 0.45 $\mu \mathrm{m}$ mixed cellulose membrane filters from Whatman (Kent, UK). Then $3 \mathrm{~mL}$ of filtered wastewater were spiked with labeled internal standards (20 ng of caffeine- ${ }^{13} \mathrm{C}_{3}$ and $200 \mathrm{ng}$ 1,7-dimethyluric acid- $\mathrm{d}_{3}$ ) and, if necessary, the $\mathrm{pH}$ was adjusted to $6.0-7.5$ with $12 \% \mathrm{HCl}$ (v/v). Samples were loaded on Oasis HLB cartridges $(3 \mathrm{~mL}, 60 \mathrm{mg})$, previously conditioned with $6 \mathrm{~mL}$ of $\mathrm{MeOH}$ and $3 \mathrm{~mL}$ of water. Cartridges were vacuum-dried for 10 minutes, wrapped in aluminum foil and immediately stored at $-20{ }^{\circ} \mathrm{C}$. For analysis, cartridges were eluted with $2 \mathrm{~mL}$ of methanol and the extract was evaporated to dryness under a nitrogen stream. Dry residues were redissolved in $100 \mu \mathrm{L} \mathrm{MeOH-ultrapure} \mathrm{water} \mathrm{(20:80,} \mathrm{v/v),}$ centrifuged and transferred into glass vials for instrumental analysis. One $\mu \mathrm{L}$ of the final extract was injected into the liquid chromatography coupled to tandem mass spectrometry system (LC-MS/MS). The analyses were done by high-performance liquid chromatography (1200 Series pumps system, Agilent Technologies, CA) coupled to a triple quadrupole mass spectrometer (AB SCIEX QqQ 5500, Ontario, Canada). Samples were analysed using the positive electrospray ionization mode. Experimental conditions and detailed analytical conditions are described in Table S3 and S4 and in more detail in Senta et al., 2015.

\subsection{Daily mass loads and back-calculation of consumption}


The daily mass loads (g/day) of the selected analytes were calculated multiplying the measured concentrations of caffeine and metabolites (ng/L) by the daily flow rate of wastewater (L/day) at the entry of each WWTP.

Caffeine consumption was back-calculated using the approach proposed for illicit drugs by Zuccato et al., 2008. Specific correction factors were developed taking into account the percentage of urinary excretion of each metabolite and the molar mass ratio of the parent compound to the metabolite. All the pharmacokinetic studies accessible in the literature which reported data on the human urinary excretion of caffeine after oral administration (eight in all, see Supplemental Information) were reviewed to develop a specific correction factor for back-calculating caffeine intake by the population. The mean percentage of excretion of caffeine and its metabolites was calculated by weighting the number of subjects in each study. The total uncertainty related to the back-calculation procedure was evaluated as the standard deviation (SD) of the mean percentage of excretion (Table 1). This method had been previously proposed for refining the correction factors of the most used illicit drugs (Castiglioni et al., 2013; Gracia-Lor et al., 2016). 
Table 1. Metabolic profiles of caffeine and its main metabolites in human urine (from pharmacokinetic studies and spot urine analysis) and from the levels measured in wastewater.

\begin{tabular}{|l|c|c|}
\hline \multicolumn{1}{|c|}{ Compound } & $\begin{array}{c}\text { Mean excretion (\%) from } \\
\text { pharmacokinetic studies } \\
\text { (SD) }\end{array}$ & $\begin{array}{c}\text { Geometric mean from spot } \\
\text { urine analysis (95\%CI) (2466 } \\
\text { subjects) }\end{array}$ \\
\hline caffeine (1,3,7-trimethylxanthine) & $1.7(1.0)$ & $\begin{array}{c}\text { Mean excretion (\%) from } \\
\text { wastewater analysis (SD) } \\
\text { (70 samples) }\end{array}$ \\
\hline paraxanthine (1,7-dimethylxanthine) & $4.6(1.4)$ & $20.9(6.0)$ \\
\hline 1-methylxanthine & $10.0(3.4)$ & $7.47(6.73-8.29)$ \\
\hline 7-methylxanthine & $3.1(1.2)$ & $17.1(15.4-19.0)$ \\
\hline 1-methyluric acid & $16.5(6.2)$ & $31.4(28.6-34.3)$ \\
\hline 1,7-dimethyluric acid & $6.7(2.3)$ & $39.4(35.8-43.4)$ \\
\hline theophylline (1,3-dimethylxanthine) & $0.6(0.4)$ & $12.2(11.0-13.6)$ \\
\hline theobromine (3,7-dimethylxanthine) & $1.5(1.3)$ & $0.872(0.796-0.955)$ \\
\hline 1,3-dimethyluric acid & $1.6(0.7)$ & $12.4(11.4-13.5)$ \\
\hline 3,7-dimethyluric acid & $0.2(0.4)$ & $3.51(3.17-3.89)$ \\
\hline 3-methylxanthine & $2.0(1.1)$ & $11.6(2.0)$ \\
\hline
\end{tabular}

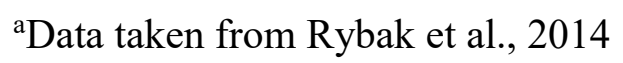




\section{RESULTS AND DISCUSSION}

\subsection{Caffeine biomarkers for back-calculation}

Selecting a substance as a biomarker is not easy to achieve as it must have specific characteristics (Gracia-Lor et al., 2016): i) be excreted in measurable quantities in wastewater; ii) be released to sewers exclusively from human excretion; iii) be unique to human metabolism to ensure that it comes only from human excretion and not from exogenous sources; iv) have low adsorption for suspended particulate; v) be stable in wastewater during in-sewer transport, and during storage and analysis.

Each substance for this investigation was tested as a suitable biomarker of caffeine consumption as described above. Caffeine itself is not a good candidate because it comes not only from coffee but also from other sources. Caffeine metabolites too may originate from other naturally occurring alkaloids with similar structures, such as theobromine and theophylline, which themselves are also caffeine metabolites (Figure 1). Theobromine is present in cocoa beans (and subsequently in chocolate), tea leaves and cola beans. Theophylline is present in tea leaves in small amounts but is also used medically, for instance for asthma and other lung diseases (Senchina et al., 2014). Specifically, among five caffeine metabolites studied, 1-methylxanthine and 1-methyluric acid are also metabolites of theophylline, while 7-methylxanthine is the major metabolite of theobromine. Paraxanthine and 1,7-dimethyluric acid however, are exclusively metabolites of caffeine (Figure 1). Thus, they are potentially the most suitable biomarkers to back-calculate the amount of caffeine consumed, i.e. the consumption of all products containing caffeine (coffee, chocolate, tea, etc). As they come only from human excretion and not from exogenous sources, their presence can play an important role in identifying fresh water or ground water contaminated by sewage. 
<smiles>Cn1c(=O)c2[nH]c(=O)[nH]c2n(C)c1=O</smiles>

1,3-dimethyluric acid<smiles>Cn1c(=O)c2[nH]cnc2n(C)c1=O</smiles>

theophylline (1,3-dimethylxanthine)

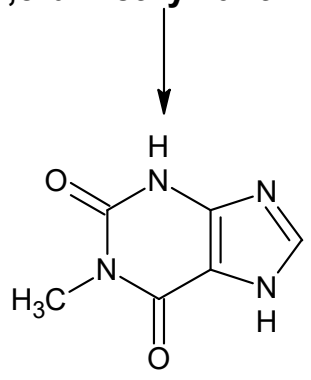

1-methylxanthine<smiles></smiles>

1-methyluric acid<smiles></smiles>

3-methylxanthine<smiles>Cn1c(=O)[nH]c(=O)c2c1[nH]c(=O)n2C</smiles>

3,7-dimethyluric acid<smiles>Cn1c(=O)c2c([nH]c(=O)n2C)n(C)c1=O</smiles>

1,3,7-trimethyluric acid<smiles>Cc1c2c(=O)n(C)c(=O)n(C)c2nn1C</smiles>

caffeine

(1,3,7-trimethylxanthine)

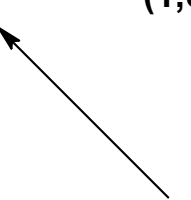<smiles>Cn1c(=O)[nH]c2ncn(C)c2c1=O</smiles>

paraxanthine (1,7-dimethylxanthine)<smiles>CC(=O)Nc1c(NC=O)[nH]c(=O)n(C)c1=O</smiles>

5-acetylamino-6-formylamino -3-methyluracil

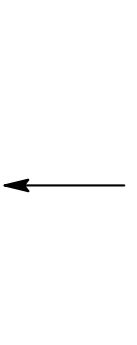

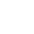<smiles></smiles>

theobromine (3,7-dimethylxanthine)<smiles></smiles>

7-methylxanthine<smiles>Cn1c(=O)[nH]c2[nH]c(=O)[nH]c(=O)c21</smiles>

7-methyluric acid<smiles>Cn1c(=O)[nH]c2[nH]c(=O)n(C)c2c1=O</smiles>

1,7-dimethyluric acid

\section{5-acetylamino-6-amino-3- methyluracil}

Figure 1. Metabolic pathway of caffeine in humans 


\subsection{Metabolic profiles in wastewater and in human urine}

According to the human urinary excretion profile of caffeine, the mass loads of 1methyluric acid should be the highest, followed by 1-methylxanthine, 1,7-dimethyluric acid, paraxanthine, 7-methylxanthine and finally, caffeine (Table 1). However, the quantitative profiles of caffeine and the metabolites calculated from wastewater analysis did not completely agree with the human excretion profile. The mass loads (mean of the ten cities) decreased as follows: 7-methylxanthine $>$ paraxanthine $>$ caffeine $>1$-methylxanthine $>1,7-$ dimethyluric acid > 1-methyluric acid (Figure 2). Hence, there are large differences from the human excretion profile of caffeine. We therefore included supplementary data from spot urine analysis in our comparison (Table 1). These percentages (geometric mean, 95\% CI) were obtained from Rybak et al., 2014, who recently measured caffeine and 14 metabolites in more than 2000 urine samples. We calculated also the percentages of excretion using the concentrations measured in wastewater in the ten European cities (Table 1). Each metabolite is reported as a percentage of the sum of the levels of metabolites plus caffeine measured in wastewater, following the procedure employed by Castiglioni et al., 2011 to calculate the metabolic profile of cocaine in wastewater and in human urine. The excretion profiles of caffeine and its metabolites were calculated using median values because of the high variability of the concentrations. 


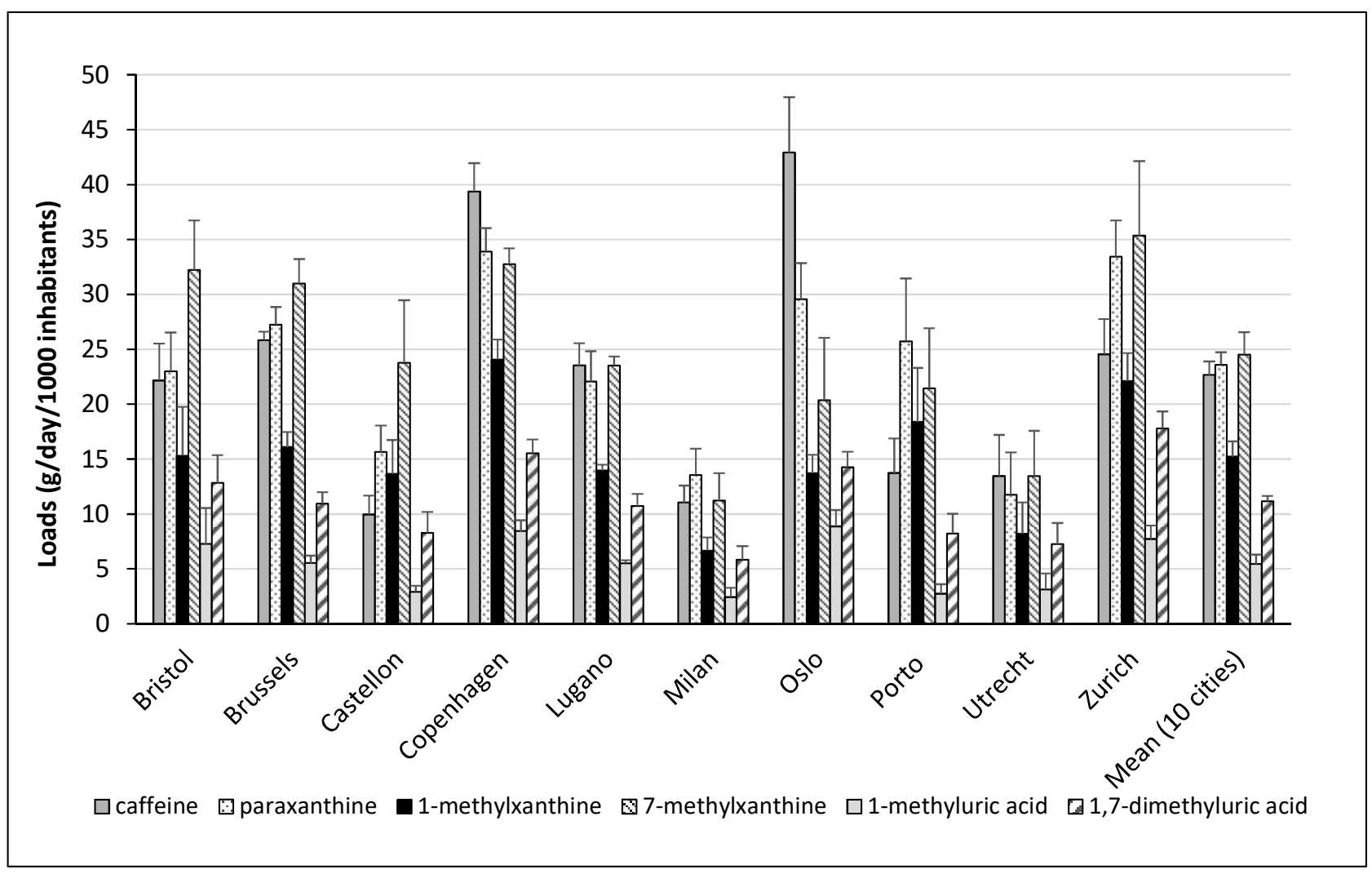

Figure 2. Normalized mass loads (g/day/1000 inhabitants) of caffeine and its metabolites in ten European cities in March 2015 and April 2015 (Porto). Means \pm standard deviation (SD) of seven-day samples (only the upper limit of the SD bar is shown). 
Data from wastewater could be reasonably compared with the profiles in spot urine samples, since they indicate respectively the profiles of excretion from an entire community and from single individuals. Percentages were comparable for 1-methylxanthine and 7methylxanthine acid in wastewater and spot urine samples, but higher than in pharmacokinetic studies (Table 1). This can be easily explained by the fact that they are also metabolites of theophylline and theobromine respectively. The percentage of caffeine in wastewater (21\%) was much higher than expected from spot urine analysis and pharmacokinetic studies $(1.8 \%$ and $1.7 \%)$. There might therefore be other sources of caffeine contributing to the total amount in wastewater (e.g., coffee grounds that are disposed down of the sink drain, disposal of coffee that was not drunk or improper disposal of caffeine for pharmacological use). In contrast, for 1-methyluric acid the percentage in wastewater was lower than in urine and in pharmacokinetic studies. A possible explanation could be degradation of this compound in wastewater such as in-sewer, during transport or during storage. This should be verified by in-sewer experiments and additional modeling studies.

Some differences were observed for paraxanthine $(22.1 \%$ of the total in wastewater, $4.6 \%$ in pharmacokinetic studies and $7.5 \%$ in spot urine samples); however for 1,7dimethyluric acid the results were comparable (approximately $12 \%$ of the measured concentrations in wastewater and in spot urine samples, and $4.3-12.6 \%$ of the administered dose in pharmacokinetic studies (see data in SI)). Taking to account of all these considerations, 1,7-dimethyluric acid seemed to be the most suitable biomarker for the backcalculation of caffeine. The mean percentage of excretion of this metabolite weighted by the number of subjects in each study (6.7\%) and the 1,7-dimethyluric acid/caffeine molecular mass ratio were used to obtain the correction factor $(\mathrm{CF})$, according to the following equation:

$$
C F=\frac{M w_{\text {caffeine }} / M w_{1,7-\text { dimethyluric acid }}}{\text { Mean excretion }{ }_{1,7-\text { dimethyluric acid }}}=\frac{194.08 / 196.06}{0.067}=14.8
$$


where $\mathrm{Mw}$ is the molecular weight and the mean excretion is the weighted mean of the percentage of excretion of the target metabolite.

\subsection{Estimation of caffeine consumption}

Using the proposed correction factor, caffeine consumption (in $\mathrm{mg} / \mathrm{day} /$ person) in each city was calculated based on the wastewater measurements of 1,7-dimethyluric acid. The mean daily consumption of caffeine per capita ranged from $263 \mathrm{mg} /$ day/person in Zurich to $87 \mathrm{mg} /$ day/person in Milan (Table 2). These data match the mean daily caffeine intake in Europe of around $300 \mathrm{mg} /$ day/person estimated by the European Food Safety Authority (means range from 37 to $320 \mathrm{mg} /$ day/person estimated from individual surveys for adults between 18 and 64 years) (European Food Safety Authority (EFSA), 2015).

For a more accurate comparison, we compared our wastewater analysis data to the amount of coffee consumed per country per capita (per person on average), which reflects the imports of coffee by each country, according to the International Coffee Organization (ICO) (International Coffee Organization (ICO), 2015). We converted the per capita consumption (in $\mathrm{kg} /$ person) of coffee to the daily intake of caffeine per person considering that dry coffee beans contain about $1.1 \%$ of caffeine in Arabica and about $2.2 \%$ in Robusta coffee. In 2015, around $60 \%$ of the coffee exported was Arabica ("International Coffee Organization,” 2015), but the proportion can change from country to country. For instance, according to Garattini, 1993, consumer countries can be classified in three levels: (a) where consumption of Arabica accounts for more than 70\% (Switzerland and Northern European countries, i.e. Norway and Denmark); (b) where consumption of Arabica is around 50\% (Italy, the Netherlands, Belgium and the UK); (c) where consumption of Robusta predominates (Spain and Portugal) (Table 2). In addition, the amount of caffeine extracted varies with the preparation method, ranging from $75 \%$ in boiled coffee to nearly $100 \%$ in filtered coffee. To estimate the amount of 
caffeine in the coffee we took $1.1 \%$ for countries classified in group (a), 1.6\% (i.e. mean caffeine content in Arabica and in Robusta) for countries belonging to group (b) and 2.2\% for countries in group (c). In all cases, we assumed 95\% extraction efficiency, as previously proposed (Fredholm et al., 1999).

For four cities (Oslo, Copenhagen, Zurich and Brussels), the difference was 20\% or less. The amounts for Castellón, Utrecht, Milan, Lugano and Porto estimated from wastewater analysis were lower than indicated by the coffee trade figures, and higher in Bristol. This might be due to different factors: first of all, we compared data from whole country with data in a specific city, while population habits might be different. This was the case for Zurich and Lugano, two Swiss cities: a 20\% difference was obtained for Zurich (410,000 inhabitants), whilst it was around 50\% for Lugano (100,000 inhabitants). Secondly, we compared annual coffee trade figures with caffeine estimated through wastewater analysis in one week. Finally, data obtained through back-calculation refer to the amount of caffeine consumed in all products that contain relatively large amounts such as coffee, chocolate, soft drinks and medications. Thus, larger amounts of caffeine estimated through the wastewater analysis in Zurich, Copenhagen, and especially in Bristol, might be due to higher consumption of other products in those countries. Switzerland is in fact the country with the highest per capita consumption of chocolate, and the UK is also among the countries with the highest consumption, according to different sources (Statista, 2015; Target Map, 2015)). Another reason might be the fact that the caffeine content of coffee in the UK is higher than in other countries (Barone and Roberts, 1996). Furthermore, tea containing around 3\% of caffeine is the most popular drink in the UK today, and contributes to caffeine consumption. In five cities, the difference was of at least $50 \%$. 
Table 2. Caffeine consumption estimated from wastewater analysis and using coffee trade data for the countries investigated. The difference was calculated between the estimates from international statistics and from wastewater analysis.

\begin{tabular}{|l|c|c|c|c|c|}
\hline & $\begin{array}{c}\text { Caffeine from } \\
\text { wastewater analysis }\end{array}$ & \multicolumn{3}{|c|}{ Caffeine from international statistics* } \\
\hline $\begin{array}{c}\text { Cities investigated } \\
\text { (country) }\end{array}$ & $\begin{array}{c}\text { mg caffeine/day/person } \\
\text { (SD) }\end{array}$ & Kg coffee/year/person* & $\begin{array}{c}\text { Type of coffee mostly } \\
\text { consumed }\end{array}$ & mg caffeine/day/person \\
\hline Bristol (UK) & $190(37)$ & 3.3 & $50 \%$ Arabica-50\% Robusta & 137 \\
\hline Brussels (Belgium) & $162(15)$ & 4.3 & $50 \%$ Arabica-50\% Robusta & 179 \\
\hline Castellón(Spain) & $122(28)$ & 4.5 & Robusta & 258 \\
\hline Copenhagen (Denmark) & $229(19)$ & 6.9 & Arabica & 16 \\
\hline Lugano (Switzerland) & $97(16)$ & 7.6 & Arabica & 198 \\
\hline Milan (Italy) & $86(18)$ & 5.6 & $50 \%$ Arabica-50\% Robusta & 218 \\
\hline Oslo (Norway) & $211(21)$ & 8.7 & Arabica & 233 \\
\hline Porto (Portugal) & $121(27)$ & 4.8 & Robusta & 249 \\
\hline Utrecht (The Netherlands) & $107(28)$ & 5.3 & $50 \%$ Arabica-50\% Robusta & 275 \\
\hline Zurich (Switzerland) & $263(23)$ & 7.6 & Arabica & 221 \\
\hline
\end{tabular}

*Source: International Coffee Organization (ICO), 2015 (http://www.ico.org/coffee-trade-statistics-infographics.asp)

a(Garattini, 1993) 
The aim of the comparison between the amount of caffeine consumed, estimated from the wastewater analysis, and coffee consumption figures from international trade was mainly to check whether the proposed metabolite was a suitable biomarker of consumption. The results indicate that 1,7-dimethyluric acid can be used for this purpose, although additional studies are needed to validate this approach, including more extensive wastewater sampling campaigns in different countries.

Additional information on the current proportions (percentages) of commercial varieties of coffee consumed in each country is also needed for more accurate comparisons. There are some differences between coffee consumption data, in terms of the amount consumed in each country per capita, published by different sources (for instance, between the ICO (International Coffee Organization (ICO), 2015) which is based on coffee imports and exports and Euromonitor International (Caffeine Informer, 2016), which deals with local business information). This is another factor that may influence the accuracy of a data comparison.

Additionally, only eight studies could be found dealing with the human excretion of caffeine, so more pharmacological studies are essential to improve the reliability of urinary excretion profiles and the correction factors used to back-calculate caffeine consumption. At present, these studies are scarce and most are quite old and based on a small number of subjects (Gracia-Lor et al., 2016).

\section{CONCLUSIONS}

Profiles of caffeine metabolites in wastewater reasonably matched the profiles in spot urine samples suggesting that the analysis in wastewater might reflect the collective consumption of caffeine-containing products.

We selected 1,7-dimethyluric acid for caffeine back-calculation because it is an exclusive human metabolite of caffeine and so it is only produced by consumption of products 
containing caffeine (i.e. coffee, tea, chocolate, etc.). The percentage of its excretion from pharmacokinetic studies is similar to the profiles found in urine and in wastewater (estimated from 70 influent wastewater samples collected in ten European cities). The mean daily consumption of caffeine per capita, estimated from wastewater analysis using the correction factor proposed, matched the mean daily caffeine intake (from 37 to $320 \mathrm{mg} /$ day/person estimated from individual surveys for adults 18-64 years old). In four cities a good correlation was seen between wastewater analysis and the amount of coffee consumed in the country per capita. Several factors might explain discrepancies in the other six cities. For instance the estimation of coffee consumption on the basis of the imports of coffee by each country is influenced by many uncertainties, so it is hard to estimate the consumption of other commodities contributing to caffeine intake. Furthermore, the correction factor may be imprecise due to uncertainties in the metabolism studies in the literature. Thus, new studies are needed about the metabolism and urinary excretion of caffeine in realistic intake amounts. Stability tests of biomarkers in sewers are also needed.

\section{CONTRIBUTIONS}

Emma Gracia-Lor, Ettore Zuccato and Sara Castiglioni planned and designed the study. The collection of the wastewater samples was organized by all authors. Emma GraciaLor analyzed the samples and interpreted the results with the input of Nikolaos I. Rousis and Sara Castiglioni. Emma Gracia-Lor drafted the manuscript, which was critically revised by all co-authors. All authors are aware of the content, and accept responsibility, for the manuscript.

\section{ACKNOWLEDGMENTS}

Financial support from the SEWPROF Marie Curie ITN project 'A new paradigm in drug use and human health risk assessment: Sewage profiling at the community level' [grant 
agreement 317205] supported by the European Union's Seventh Framework Programme for research, technological development and demonstration and from the COST Action ES1307 "SCORE - Sewage biomarker analysis for community health assessment" is gratefully acknowledged. Emma Gracia-Lor extends her gratitude to Generalitat Valenciana, Conselleria d'Educació, Investigació, Cultura i Esport for her postdoctoral contract (APOSTD/2015, Programa VALi $+d)$. Alexander van Nuijs acknowledges FWO Flanders for financial support. We are grateful to Christoph Ort for his comments and suggestions and to the personnel from all WWTPs for their support in wastewater sampling, particularly Francesco Poretti and Armando Foletti from Consorzio Depurazione Acque Lugano e Dintorni (CDALED) in Lugano for their kind support. 


\section{REFERENCES}

Arab, L., Blumberg, B., 2008. Introduction to the proceedings of the Third International Scientific Symposium on Tea and Human Health. J. Nutr. 138, 1826-1528. doi:10.3945/ajen.113.060186.Am

Baker, D.R., Barron, L., Kasprzyk-Hordern, B., 2014. Illicit and pharmaceutical drug consumption estimated via wastewater analysis. Part A: Chemical analysis and drug use estimates. Sci. Total Environ. 487, 629-641. doi:10.1016/j.scitotenv.2013.11.107

Barone, J.J., Roberts, H.R., 1996. Caffeine consumption. Food Chem. Toxicol. 34, 119-129.

Butt, M.S., Tauseef, S.M., 2011. Coffee and its Consumption: Benefits and Risks. Crit. Rev. Food Sci. Nutr. 51, 363-373. doi:10.1080/10408390903586412

Caffeine Informer, 2016. Caffeine (coffee) consumption by country. http://www.caffeineinformer.com/caffeine-what-the-world-drinks. (accessed 3.1.16).

Castiglioni, S., Bagnati, R., Melis, M., Panawennage, D., Chiarelli, P., Fanelli, R., Zuccato, E., 2011. Identification of cocaine and its metabolites in urban wastewater and comparison with the human excretion profile in urine. Water Res. 45, 5141-5150. doi:10.1016/j.watres.2011.07.017

Castiglioni, S., Bijlsma, L., Covaci, A., Emke, E., Hernández, F., Reid, M., Ort, C., Thomas, K. V., Van Nuijs, A.L.N., De Voogt, P., Zuccato, E., 2013. Evaluation of uncertainties associated with the determination of community drug use through the measurement of sewage drug biomarkers. Environ. Sci. Technol. 47, 1452-1460. doi:10.1021/es302722f

Chou, K.H., Bell, L.N., 2007. Caffeine content of prepackaged national-brand and privatelabel carbonated beverages. J. Food Sci. 72. doi:10.1111/j.1750-3841.2007.00414.x

Derbyshire, E., Abdula, S., 2008. Habitual caffeine intake in women of childbearing age. J.Hum.Nutr.Diet. 21, 159-164.

European Food Safety Authority (EFSA), 2015. Scientific Opinion in the safety of caffeine. 
Eur. Food Saf. J. doi:10.2903/j.efsa.20YY.NNNN

Fitt, E., Pell, D., Cole, D., 2013. Assessing caffeine intake in the United Kingdom diet. Food Chem. 140, 421-426. doi:10.1016/j.foodchem.2012.07.092

Fredholm, B.B., Bättig, K., Holmén, J., Nehlig, A., Zvartau, E.E., 1999. Actions of caffeine in the brain with special reference to factors that contribute to its widespread use. Pharmacol. Rev. 51, 83-133. doi:0031-6997/99/5101-0083\$03.00/0

Garattini, S., 1993. Caffeine, Coffee, and Health. Raven Press, New York.

Gracia-Lor, E., Zuccato, E., Castiglioni, S., 2016. Refining correction factors for backcalculation of illicit drug use. Sci. Total Environ. 573, 1648-1659. doi:10.1016/j.scitotenv.2016.09.179

Heckman, M.A., Weil, J., de Mejia, E.G., 2010. Caffeine (1, 3, 7-trimethylxanthine) in foods: A comprehensive review on consumption, functionality, safety, and regulatory matters. J. Food Sci. 75, 77-87. doi:10.1111/j.1750-3841.2010.01561.x

Higdon, J. V., Frei, B., 2006. Coffee and Health: A Review of Recent Human Research. Crit. Rev. Food Sci. Nutr. 46, 101-124. doi:10.1080/10408390500400009

International Coffee Organization (ICO), 2015. Global coffee trade. http://www.ico.org/coffee-trade-statistics-infographics.asp (accessed 1.15.16).

International Coffee Organization, 2015. http://www.ico.org/

Lopes, A., Silva, N., Bronze, M.R., Ferreira, J., Morais, J., 2014. Analysis of cocaine and nicotine metabolites in wastewater by liquid chromatography-tandem mass spectrometry. Cross abuse index patterns on a major community. Sci. Total Environ. 487, 673-680. doi:10.1016/j.scitotenv.2013.10.042

Mitchell, D.C., Knight, C. A., Hockenberry, J., Teplansky, R., Hartman, T.J., 2014. Beverage caffeine intakes in the U.S. Food Chem. Toxicol. 63, 136-142. doi:10.1016/j.fct.2013.10.042 
Ort, C., van Nuijs, A.L.N., Berset, J.D., Bijlsma, L., Castiglioni, S., Covaci, A., de Voogt, P., Emke, E., Fatta-Kassinos, D., Griffiths, P., Hernández, F., González-Mariño, I., Grabic, R., Kasprzyk-Hordern, B., Mastroianni, N., Meierjohann, A., Nefau, T., Östman, M., Pico, Y., Racamonde, I., Reid, M., Slobodnik, J., Terzic, S., Thomaidis, N., Thomas, K. V., 2014. Spatial differences and temporal changes in illicit drug use in Europe quantified by wastewater analysis. Addiction 109, 1338-1352. doi:10.1111/add.12570

Reid, M.J., Langford, K.H., Mørland, J., Thomas, K. V., 2011. Analysis and interpretation of specific ethanol metabolites, ethyl sulfate, and ethyl glucuronide in sewage effluent for the quantitative measurement of regional alcohol consumption. Alcohol. Clin. Exp. Res. 35, 1593-1599. doi:10.1111/j.1530-0277.2011.01505.x

Rodríguez-Álvarez, T., Racamonde, I., González-Mariño, I., Borsotti, A., Rodil, R., Rodríguez, I., Zuccato, E., Quintana, J.B., Castiglioni, S., 2015. Alcohol and cocaine coconsumption in two European cities assessed by wastewater analysis. Sci. Total Environ. 536, 91-8. doi:10.1016/j.scitotenv.2015.07.016

Rousis, N.I., Zuccato, E., Castiglioni, S., 2017. Wastewater-based epidemiology to assess human exposure to pyrethroid pesticides. Environ. Int. 99, 213-220. doi:10.1016/j.envint.2016.11.020

Rybak, M.E., Pao, C.I., Pfeiffer, C.M., 2014. Determination of urine caffeine and its metabolites by use of high-performance liquid chromatography-tandem mass spectrometry: Estimating dietary caffeine exposure and metabolic phenotyping in population studies. Anal. Bioanal. Chem. 406, 771-784. doi:10.1007/s00216-013-7506-9

Senchina, D.S., Hallam, J.E., Kohut, M.L., Nguyen, N.A., Perera, M.A.D.N., 2014. Alkaloids and athlete immune function: caffeine, theophylline, gingerol, ephedrine, and their congeners. Exerc. Immunol. Rev. 20, 68-93.

Statista, 2015. Per capita consumption of chocolate confectionery worldwide in 2015, by key 
markets (in kilograms). https://www.statista.com/statistics/263779/per-capitaconsumption-of-chocolate-in-selected-countries-in-2007/ (accessed 2.2.17).

Target Map, 2015. The Chocolate League Tables 2014: Top 20 consuming nations. http://www.targetmap.com/viewer.aspx?reportId=38038 (accessed 2.2.17).

Thomas, K. V., Bijlsma, L., Castiglioni, S., Covaci, A., Emke, E., Grabic, R., Hernández, F., Karolak, S., Kasprzyk-Hordern, B., Lindberg, R.H., Lopez de Alda, M., Meierjohann, A., Ort, C., Pico, Y., Quintana, J.B., Reid, M., Rieckermann, J., Terzic, S., van Nuijs, A.L.N., de Voogt, P., 2012. Comparing illicit drug use in 19 European cities through sewage analysis. Sci. Total Environ. 432, 432-439. doi:10.1016/j.scitotenv.2012.06.069

Thomas, K. V., Reid, M.J., 2011. What Else Can the Analysis of Sewage for Urinary Biomarkers Reveal About Communities? Environ. Sci. Technol. 45, 7611-7612. doi:10.1021/es202522d

Yang, Z., D’Uriac, M.A., Goggins, S., Kasprzyk-Hordern, B., Thomas, K. V., Frost, C.G., Estrela, P., 2015. A novel DNA biosensor using a ferrocenyl intercalator applied to the potential detection of human population biomarkers in wastewater. Environ. Sci. Technol. 49, 5609-5617. doi:10.1021/acs.est.5b00637

Zuccato, E., Chiabrando, C., Castiglioni, S., Bagnati, R., Fanelli, R., 2008. Estimating community drug abuse by wastewater analysis. Environ. Health Perspect. 116, 10271032. doi:10.1289/ehp. 11022 


\section{SUPPLEMENTAL INFORMATION}

\section{ESTIMATION OF CAFFEINE INTAKE FROM ANALYSIS OF CAFFEINE METABOLITES IN}

\section{WASTEWATER}

Emma Gracia-Lor ${ }^{a, b *}$, Nikolaos I. Rousisa, Ettore Zuccato ${ }^{a}$, Richard Bade ${ }^{b, c}$, Jose Antonio BazLomba $^{d, e}$, Erika Castrignanò ${ }^{f}$, Ana Causanilles ${ }^{g}$, Félix Hernández ${ }^{b}$, Barbara Kasprzyk-Hordern ${ }^{f}$, Juliet Kinyua ${ }^{h}$, Ann-Kathrin McCalli, Alexander L.N. van Nuijsh ${ }^{\mathrm{h}}$, Benedek G. Plósz ${ }^{\mathrm{j}, \mathrm{k}}$, Pedram Ramin ${ }^{\mathrm{j}, \mathrm{I}}$, Yeonsuk Ryu ${ }^{d, e}$, Miguel M. Santos ${ }^{m, n}$, Kevin Thomas ${ }^{d, o}$, Pim de Voogt ${ }^{g, p}$, Zhugen Yang ${ }^{f, q}$ and Sara Castiglionia*

aIRCCS - Istituto di Ricerche Farmacologiche "Mario Negri", Department of Environmental Health Sciences, Via La Masa 19, 20156, Milan, Italy

${ }^{\text {b}}$ Research Institute for Pesticides and Water, University Jaume I, Avda. Sos Baynat s/n, E-12071, Castellon, Spain

'School of Pharmacy and Medical Sciences, University of South Australia, Adelaide, South Australia 5000, Australia

${ }^{\mathrm{d} N o r w e g i a n}$ Institute for Water Research (NIVA), Gaustadalléen 21, 0349 Oslo, Norway

e Faculty of Medicine, University of Oslo, PO box 1078 Blindern, 0316, Oslo, Norway

fUniversity of Bath, Department of Chemistry, Faculty of Science, Bath BA2 7AY, United Kingdom gKWR Watercycle Research Institute, Chemical Water Quality and Health, P.O. Box 1072, 3430 BB, Nieuwegein, The Netherlands

${ }^{\mathrm{h}}$ Toxicological Center, Department of Pharmaceutical Sciences, Campus Drie Eiken, University of Antwerp, Universiteitsplein 1, 2610 Antwerp, Belgium 
'Eawag, Swiss Federal Institute of Aquatic Science and Technology, CH-8600, Dübendorf, Switzerland

'Department of Environmental Engineering, Technical University of Denmark, Bygningstorvet, Building 115, DK-2800 Kgs. Lyngby, Denmark

${ }^{k}$ Department of Chemical Engineering, University of Bath, Claverton Down, Bath BA2 7AY, UK

'Department of Chemical and Biochemical Engineering, Technical University of Denmark, Søltofts Plads, Building 229, DK-2800 Kgs. Lyngby, Denmark

${ }^{m}$ CIMAR/CIIMAR-Interdisciplinary Centre of Marine and Environmental Research, University of Porto, Avenida General Norton de Matos, S/N, 4450-208 Matosinhos, Portugal

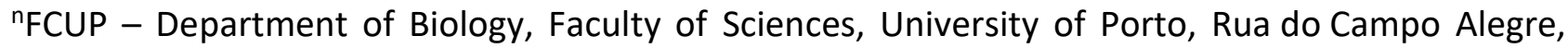
4169-007 Porto, Portugal

${ }^{\circ}$ Queensland Alliance for Environmental Health Sciences (QAEHS), University of Queensland, 39 Kessels Road Coopers Plains, Queensland 4108 Australia

PInstitute for Biodiversity and Ecosystem Dynamics, University of Amsterdam, P.O. Box 94248, 1090 GE, Amsterdam, The Netherlands

aDivision of Biomedical Engineering, School of Engineering, University of Glasgow, Glasgow G12 8LT United Kingdom

\section{*Corresponding author:}

E-mail addresses: lor@uji.es (E. Gracia-Lor), sara.castiglioni@marionegri.it (S. Castiglioni) 


\section{Table of Contents}

Table S1. Excretory profile of caffeine and its metabolites

Table S2. Main characteristics of the wastewater treatment plants (WWTPs) investigated

Table S3. Precursor and products ions of the analyzed compounds with the associated collision energies

Table S4. Linearities, recoveries, repeatibilities and quantification limits 
Table S1. Excretory profile of caffeine and its metabolites

Caffeine (1,3,7-trimethylxanthine)

\begin{tabular}{|c|c|c|c|c|c|}
\hline References & Dose & Subjects treated & Duration (h) & $\begin{array}{c}\text { Caffeine excretion } \\
(\%)\end{array}$ & SD \\
\hline (Latini et al., 1981) & $5 \mathrm{mg} / \mathrm{kg}$ & 4 & 72 & 1.8 & \\
\hline $\begin{array}{c}\text { (Dan-Shya et al., } \\
1983 \text { ) }\end{array}$ & $\begin{array}{l}\text { Theophylline }(7.5 \mathrm{mg} / \mathrm{kg}) \text { and } \\
\text { caffeine }(7.5 \mathrm{mg} / \mathrm{kg}) 2 \text { weeks later }\end{array}$ & 6 & 60 & 3.7 & 1 \\
\hline $\begin{array}{l}\text { (Callahan et al., } \\
\text { 1982) }\end{array}$ & $5 \mathrm{mg} / \mathrm{kg}\left({ }^{14} \mathrm{C}\right.$-labeled caffeine) & 10 & 48 & 1.1 & 0.59 \\
\hline $\begin{array}{c}\text { (Callahan et al., } \\
\text { 1983) }\end{array}$ & $5 \mathrm{mg} / \mathrm{kg}\left(2-{ }^{14} \mathrm{C}\right)$ caffeine & $\begin{array}{c}4 \text { males } \\
4 \text { females oral contraceptives } \\
4 \text { ovulating females }\end{array}$ & 96 & $\begin{array}{l}1.46 \\
2.61 \\
1.33\end{array}$ & $\begin{array}{l}0.4 \\
1.19 \\
0.45\end{array}$ \\
\hline $\begin{array}{c}\text { (Blanchard et al., } \\
\text { 1985) }\end{array}$ & $5 \mathrm{mg} / \mathrm{kg}$ & $\begin{array}{l}5 \text { (elderly) } \\
7 \text { (young) }\end{array}$ & 24 & $\begin{array}{l}1.93 \\
2.35\end{array}$ & $\begin{array}{l}0.57 \\
2.05\end{array}$ \\
\hline (Scott et al., 1986) & $\begin{array}{l}123-369 \mathrm{mg} \\
300-750 \mathrm{mg}\end{array}$ & $\begin{array}{l}15 \text { pregnant } \\
9 \text { female }\end{array}$ & 24 & $\begin{array}{l}3.3 \\
2.0\end{array}$ & $\begin{array}{l}1.4 \\
1.1\end{array}$ \\
\hline $\begin{array}{c}\text { (Carrillo and Benitez, } \\
\text { 1994) }\end{array}$ & $300 \mathrm{mg}$ & 107 & 24 & 1.4 & 0.07 \\
\hline
\end{tabular}

\section{Paraxanthine (1,7-dimethylxanthine)}

\begin{tabular}{|c|c|c|c|c|c|}
\hline References & Dose & Subjects treated & Duration (h) & $\begin{array}{l}\text { Paraxanthine } \\
\text { excretion (\%) }\end{array}$ & SD \\
\hline (Latini et al., 1981) & $5 \mathrm{mg} / \mathrm{kg}$ & 4 & 72 & 5 & \\
\hline $\begin{array}{c}\text { (Dan-Shya et al., } \\
\text { 1983) }\end{array}$ & $\begin{array}{c}\text { Theophylline }(7.5 \mathrm{mg} / \mathrm{kg}) \text { and } \\
\text { caffeine }(7.5 \mathrm{mg} / \mathrm{kg}) 2 \text { weeks later }\end{array}$ & 6 & 60 & 7.1 & 1.7 \\
\hline $\begin{array}{c}\text { (Callahan et al., } \\
\text { 1982) }\end{array}$ & $5 \mathrm{mg} / \mathrm{kg}\left({ }^{14} \mathrm{C}\right.$-labeled caffeine) & 10 & 48 & 5.7 & 1.64 \\
\hline (Callahan et al., & $5 \mathrm{mg} / \mathrm{kg}\left(2-{ }^{14} \mathrm{C}\right)$ caffeine & 4 males & 96 & 5.39 & 1.63 \\
\hline
\end{tabular}




\begin{tabular}{|c|c|c|c|c|c|}
\hline 1983) & & $\begin{array}{c}4 \text { females oral contraceptives } \\
4 \text { ovulating females }\end{array}$ & & $\begin{array}{l}5.49 \\
3.45\end{array}$ & $\begin{array}{l}0.26 \\
0.18\end{array}$ \\
\hline (Grant et al., 1983) & $300 \mathrm{mg}$ & 68 & 24 & 4.8 & 2.4 \\
\hline $\begin{array}{c}\text { (Blanchard et al., } \\
\text { 1985) }\end{array}$ & $5 \mathrm{mg} / \mathrm{kg}$ & $\begin{array}{l}5 \text { (elderly) } \\
7 \text { (young) }\end{array}$ & 24 & $\begin{array}{l}3.37 \\
3.49\end{array}$ & $\begin{array}{l}1.47 \\
1.87\end{array}$ \\
\hline (Scott et al., 1986) & $\begin{array}{l}123-369 \mathrm{mg} \\
300-750 \mathrm{mg}\end{array}$ & $\begin{array}{l}15 \text { pregnant } \\
9 \text { female }\end{array}$ & 24 & $\begin{array}{l}5.8 \\
4.7\end{array}$ & $\begin{array}{l}1.1 \\
0.9\end{array}$ \\
\hline $\begin{array}{c}\text { (Carrillo and Benitez, } \\
\text { 1994) }\end{array}$ & $300 \mathrm{mg}$ & 107 & 24 & 4.08 & 0.18 \\
\hline
\end{tabular}

1-methylxanthine

\begin{tabular}{|c|c|c|c|c|c|}
\hline References & Dose & Subjects treated & Duration (h) & $\begin{array}{l}\text { 1-methylxanthine } \\
\text { excretion (\%) }\end{array}$ & SD \\
\hline (Latini et al., 1981) & $5 \mathrm{mg} / \mathrm{kg}$ & 4 & 72 & 16 & \\
\hline $\begin{array}{c}\text { (Dan-Shya et al., } \\
\text { 1983) }\end{array}$ & $\begin{array}{l}\text { Theophylline }(7.5 \mathrm{mg} / \mathrm{kg}) \text { and } \\
\text { caffeine }(7.5 \mathrm{mg} / \mathrm{kg}) 2 \text { weeks later }\end{array}$ & 6 & 60 & 10 & 3 \\
\hline $\begin{array}{l}\text { (Callahan et al., } \\
\text { 1982) }\end{array}$ & $5 \mathrm{mg} / \mathrm{kg}\left({ }^{14} \mathrm{C}\right.$-labeled caffeine) & 10 & 48 & 16.31 & 3.76 \\
\hline $\begin{array}{c}\text { (Callahan et al., } \\
\text { 1983) }\end{array}$ & $5 \mathrm{mg} / \mathrm{kg}\left(2-{ }^{14} \mathrm{C}\right)$ caffeine & $\begin{array}{c}4 \text { males } \\
4 \text { females oral contraceptives } \\
4 \text { ovulating females }\end{array}$ & 96 & $\begin{array}{c}14.88 \\
9.32 \\
12.28\end{array}$ & $\begin{array}{l}1.94 \\
1.44 \\
4.75\end{array}$ \\
\hline (Grant et al., 1983) & $300 \mathrm{mg}$ & 68 & 24 & 10.1 & 4.1 \\
\hline $\begin{array}{c}\text { (Blanchard et al., } \\
\text { 1985) }\end{array}$ & $5 \mathrm{mg} / \mathrm{kg}$ & $\begin{array}{l}5 \text { (elderly) } \\
7 \text { (young) }\end{array}$ & 24 & $\begin{array}{c}8.9 \\
9.48\end{array}$ & $\begin{array}{l}5.4 \\
3.7\end{array}$ \\
\hline (Scott et al., 1986) & $\begin{array}{l}123-369 \mathrm{mg} \\
300-750 \mathrm{mg}\end{array}$ & $\begin{array}{l}15 \text { pregnant } \\
9 \text { female }\end{array}$ & 24 & $\begin{array}{c}7.3 \\
11.4\end{array}$ & $\begin{array}{l}3.4 \\
2.1\end{array}$ \\
\hline $\begin{array}{c}\text { (Carrillo and Benitez, } \\
1994)\end{array}$ & $300 \mathrm{mg}$ & 107 & 24 & 9.13 & 0.4 \\
\hline
\end{tabular}


7-methylxanthine

\begin{tabular}{|c|c|c|c|c|c|}
\hline References & Dose & Subjects treated & Duration (h) & $\begin{array}{l}\text { 7-methylxanthine } \\
\text { excretion (\%) }\end{array}$ & SD \\
\hline (Latini et al., 1981) & $5 \mathrm{mg} / \mathrm{kg}$ & 4 & 72 & 8.5 & \\
\hline $\begin{array}{c}\text { (Dan-Shya et al., } \\
1983)\end{array}$ & $\begin{array}{l}\text { Theophylline }(7.5 \mathrm{mg} / \mathrm{kg}) \text { and } \\
\text { caffeine }(7.5 \mathrm{mg} / \mathrm{kg}) 2 \text { weeks later }\end{array}$ & 6 & 60 & 4 & 1.6 \\
\hline $\begin{array}{c}\text { (Callahan et al., } \\
\text { 1983) }\end{array}$ & $5 \mathrm{mg} / \mathrm{kg}\left(2-{ }^{14} \mathrm{C}\right)$ caffeine & $\begin{array}{c}4 \text { males } \\
4 \text { females oral contraceptives } \\
4 \text { ovulating females }\end{array}$ & 96 & $\begin{array}{l}1.84 \\
1.81 \\
2.17\end{array}$ & $\begin{array}{l}0.5 \\
0.25 \\
0.45\end{array}$ \\
\hline (Grant et al., 1983) & $300 \mathrm{mg}$ & 68 & 24 & 2.5 & 1.4 \\
\hline $\begin{array}{c}\text { (Blanchard et al., } \\
\text { 1985) }\end{array}$ & $5 \mathrm{mg} / \mathrm{kg}$ & $\begin{array}{l}5 \text { (elderly) } \\
7 \text { (young) }\end{array}$ & 24 & $\begin{array}{c}2.32 \\
2.4\end{array}$ & $\begin{array}{l}1.18 \\
1.45\end{array}$ \\
\hline (Scott et al., 1986) & $\begin{array}{l}123-369 \mathrm{mg} \\
300-750 \mathrm{mg}\end{array}$ & $\begin{array}{l}15 \text { pregnant } \\
9 \text { female }\end{array}$ & 24 & $\begin{array}{l}5 \\
4\end{array}$ & $\begin{array}{l}2.6 \\
0.3\end{array}$ \\
\hline $\begin{array}{c}\text { (Carrillo and Benitez, } \\
\text { 1994) }\end{array}$ & $300 \mathrm{mg}$ & 107 & 24 & 3.11 & 0.21 \\
\hline
\end{tabular}

1-methyluric acid

\begin{tabular}{|c|c|c|c|c|c|}
\hline References & Dose & Subjects treated & Duration (h) & $\begin{array}{c}\text { 1-methyluric acid } \\
\text { excretion (\%) }\end{array}$ & SD \\
\hline (Latini et al., 1981) & $5 \mathrm{mg} / \mathrm{kg}$ & 4 & 72 & 51 & \\
\hline $\begin{array}{c}\text { (Dan-Shya et al., } \\
1983)\end{array}$ & $\begin{array}{l}\text { Theophylline }(7.5 \mathrm{mg} / \mathrm{kg}) \text { and } \\
\text { caffeine }(7.5 \mathrm{mg} / \mathrm{kg}) 2 \text { weeks later }\end{array}$ & 6 & 60 & 21 & 8 \\
\hline $\begin{array}{c}\text { (Callahan et al., } \\
\text { 1982) }\end{array}$ & $5 \mathrm{mg} / \mathrm{kg}\left({ }^{14} \mathrm{C}\right.$-labeled caffeine) & 10 & 48 & 25.55 & 5.2 \\
\hline $\begin{array}{c}\text { (Callahan et al., } \\
\text { 1983) }\end{array}$ & $5 \mathrm{mg} / \mathrm{kg}\left(2-{ }^{14} \mathrm{C}\right)$ caffeine & $\begin{array}{c}4 \text { males } \\
4 \text { females oral contraceptives } \\
4 \text { ovulating females }\end{array}$ & 96 & $\begin{array}{l}19.89 \\
11.06 \\
16.14\end{array}$ & $\begin{array}{l}3.9 \\
1.95 \\
4.79\end{array}$ \\
\hline (Grant et al., 1983) & $300 \mathrm{mg}$ & 68 & 24 & 11.8 & 5 \\
\hline
\end{tabular}




\begin{tabular}{|c|c|c|c|c|c|}
\hline $\begin{array}{c}\text { (Blanchard et al., } \\
1985)\end{array}$ & $5 \mathrm{mg} / \mathrm{kg}$ & $\begin{array}{l}5 \text { (elderly) } \\
7 \text { (young) }\end{array}$ & 24 & $\begin{array}{l}38.12 \\
22.05\end{array}$ & $\begin{array}{c}14.23 \\
4.69\end{array}$ \\
\hline (Scott et al., 1986) & $\begin{array}{l}123-369 \mathrm{mg} \\
300-750 \mathrm{mg}\end{array}$ & $\begin{array}{c}15 \text { pregnant } \\
9 \text { female }\end{array}$ & 24 & $\begin{array}{c}9.4 \\
19.5\end{array}$ & $\begin{array}{l}3.7 \\
5.3\end{array}$ \\
\hline $\begin{array}{c}\text { (Carrillo and Benitez, } \\
1994)\end{array}$ & $300 \mathrm{mg}$ & 107 & 24 & 16.49 & 0.84 \\
\hline
\end{tabular}

\section{1,7-dimethyluric acid}

\begin{tabular}{|c|c|c|c|c|c|}
\hline References & Dose & Subjects treated & Duration (h) & $\begin{array}{l}\text { 1,7-dimethyluric acid } \\
\text { excretion (\%) }\end{array}$ & SD \\
\hline (Latini et al., 1981) & $5 \mathrm{mg} / \mathrm{kg}$ & 4 & 72 & 8.5 & \\
\hline $\begin{array}{c}\text { (Dan-Shya et al., } \\
\text { 1983) }\end{array}$ & $\begin{array}{l}\text { Theophylline }(7.5 \mathrm{mg} / \mathrm{kg}) \text { and } \\
\text { caffeine }(7.5 \mathrm{mg} / \mathrm{kg}) 2 \text { weeks later }\end{array}$ & 6 & 60 & 7.3 & 1 \\
\hline $\begin{array}{l}\text { (Callahan et al., } \\
\text { 1982) }\end{array}$ & $5 \mathrm{mg} / \mathrm{kg}\left({ }^{14} \mathrm{C}\right.$-labeled caffeine) & 10 & 48 & 4.32 & 1.64 \\
\hline $\begin{array}{c}\text { (Callahan et al., } \\
1983 \text { ) }\end{array}$ & $5 \mathrm{mg} / \mathrm{kg}\left(2-{ }^{14} \mathrm{C}\right)$ caffeine & $\begin{array}{c}4 \text { males } \\
4 \text { females oral contraceptives } \\
4 \text { ovulating females }\end{array}$ & 96 & $\begin{array}{c}6.19 \\
9 \\
6.05\end{array}$ & $\begin{array}{l}3.31 \\
2.04 \\
2.63\end{array}$ \\
\hline (Grant et al., 1983) & $300 \mathrm{mg}$ & 68 & 24 & 6 & 1.9 \\
\hline $\begin{array}{c}\text { (Blanchard et al., } \\
\text { 1985) }\end{array}$ & $5 \mathrm{mg} / \mathrm{kg}$ & $\begin{array}{l}5 \text { (elderly) } \\
7 \text { (young) }\end{array}$ & 24 & $\begin{array}{c}12.56 \\
7.81\end{array}$ & $\begin{array}{l}1.99 \\
3.36\end{array}$ \\
\hline (Scott et al., 1986) & $\begin{array}{l}123-369 \mathrm{mg} \\
300-750 \mathrm{mg}\end{array}$ & $\begin{array}{l}15 \text { pregnant } \\
9 \text { female }\end{array}$ & 24 & $\begin{array}{l}9.3 \\
7.2\end{array}$ & $\begin{array}{l}2.9 \\
2.1\end{array}$ \\
\hline $\begin{array}{c}\text { (Carrillo and Benitez, } \\
\text { 1994) }\end{array}$ & $300 \mathrm{mg}$ & 107 & 24 & 6.57 & 0.22 \\
\hline
\end{tabular}


Theophylline (1,3-dimethylxanthine)

\begin{tabular}{|c|c|c|c|c|c|}
\hline References & Dose & Subjects treated & Duration (h) & $\begin{array}{l}\text { Theophylline } \\
\text { excretion (\%) }\end{array}$ & SD \\
\hline $\begin{array}{c}\text { (Blanchard et al., } \\
1985)\end{array}$ & $5 \mathrm{mg} / \mathrm{kg}$ & $\begin{array}{l}5 \text { (elderly) } \\
7 \text { (young) }\end{array}$ & 24 & $\begin{array}{l}0.48 \\
0.77\end{array}$ & $\begin{array}{l}0.31 \\
0.69\end{array}$ \\
\hline (Scott et al., 1986) & $\begin{array}{l}123-369 \mathrm{mg} \\
300-750 \mathrm{mg}\end{array}$ & $\begin{array}{l}15 \text { pregnant } \\
9 \text { female }\end{array}$ & 24 & $\begin{array}{l}1.6 \\
0.8\end{array}$ & $\begin{array}{l}0.5 \\
0.4\end{array}$ \\
\hline $\begin{array}{c}\text { (Carrillo and Benitez, } \\
1994)\end{array}$ & $300 \mathrm{mg}$ & 107 & 24 & 0.5 & 0.04 \\
\hline
\end{tabular}

Theobromine (3,7-dimethylxanthine)

\begin{tabular}{|c|c|c|c|c|c|}
\hline References & Dose & Subjects treated & Duration (h) & $\begin{array}{l}\text { Theobromine } \\
\text { excretion (\%) }\end{array}$ & SD \\
\hline (Latini et al., 1981) & $5 \mathrm{mg} / \mathrm{kg}$ & 4 & 72 & 3.2 & \\
\hline $\begin{array}{c}\text { (Callahan et al., } \\
\text { 1982) }\end{array}$ & $5 \mathrm{mg} / \mathrm{kg}\left({ }^{14} \mathrm{C}\right.$-labeled caffeine $)$ & 10 & 48 & 1.57 & 0.46 \\
\hline $\begin{array}{c}\text { (Callahan et al., } \\
\text { 1983) }\end{array}$ & $5 \mathrm{mg} / \mathrm{kg}\left(2-{ }^{14} \mathrm{C}\right)$ caffeine & $\begin{array}{c}4 \text { males } \\
4 \text { females oral contraceptives } \\
4 \text { ovulating females }\end{array}$ & 96 & $\begin{array}{l}1.21 \\
1.18 \\
0.92\end{array}$ & $\begin{array}{l}0.29 \\
0.23 \\
0.54\end{array}$ \\
\hline (Grant et al., 1983) & $300 \mathrm{mg}$ & 68 & 24 & 1.1 & 0.6 \\
\hline $\begin{array}{c}\text { (Blanchard et al., } \\
\text { 1985) }\end{array}$ & $5 \mathrm{mg} / \mathrm{kg}$ & $\begin{array}{l}5 \text { (elderly) } \\
7 \text { (young) }\end{array}$ & 24 & $\begin{array}{l}1.22 \\
2.04\end{array}$ & $\begin{array}{l}0.79 \\
1.96\end{array}$ \\
\hline (Scott et al., 1986) & $\begin{array}{l}123-369 \mathrm{mg} \\
300-750 \mathrm{mg}\end{array}$ & $\begin{array}{l}15 \text { pregnant } \\
9 \text { female }\end{array}$ & 24 & $\begin{array}{l}4.3 \\
1.4\end{array}$ & $\begin{array}{l}3.4 \\
0.6\end{array}$ \\
\hline $\begin{array}{c}\text { (Carrillo and Benitez, } \\
1994)\end{array}$ & $300 \mathrm{mg}$ & 107 & 24 & 1.28 & 0.1 \\
\hline
\end{tabular}


1,3-dimethyluric acid

\begin{tabular}{|c|c|c|c|c|c|}
\hline References & Dose & Subjects treated & Duration (h) & $\begin{array}{l}\text { 1,3-dimethyluric } \\
\text { acid excretion (\%) }\end{array}$ & SD \\
\hline (Latini et al., 1981) & $5 \mathrm{mg} / \mathrm{kg}$ & 4 & 72 & 4 & \\
\hline $\begin{array}{c}\text { (Dan-Shya et al., } \\
\text { 1983) }\end{array}$ & $\begin{array}{l}\text { Theophylline }(7.5 \mathrm{mg} / \mathrm{kg}) \text { and } \\
\text { caffeine }(7.5 \mathrm{mg} / \mathrm{kg}) 2 \text { weeks later }\end{array}$ & 6 & 60 & 2.9 & 1 \\
\hline $\begin{array}{c}\text { (Callahan et al., } \\
\text { 1982) }\end{array}$ & $5 \mathrm{mg} / \mathrm{kg}\left({ }^{14} \mathrm{C}\right.$-labeled caffeine) & 10 & 48 & 2.05 & 0.31 \\
\hline (Grant et al., 1983) & $300 \mathrm{mg}$ & 68 & 24 & 1.2 & 0.4 \\
\hline $\begin{array}{c}\text { (Blanchard et al., } \\
\text { 1985) }\end{array}$ & $5 \mathrm{mg} / \mathrm{kg}$ & $\begin{array}{l}5 \text { (elderly) } \\
7 \text { (young) }\end{array}$ & 24 & $\begin{array}{l}3.37 \\
2.73\end{array}$ & $\begin{array}{l}0.89 \\
0.86\end{array}$ \\
\hline (Scott et al., 1986) & $\begin{array}{l}123-369 \mathrm{mg} \\
300-750 \mathrm{mg}\end{array}$ & $\begin{array}{c}15 \text { pregnant } \\
9 \text { female }\end{array}$ & 24 & $\begin{array}{l}2.6 \\
1.6 \\
\end{array}$ & $\begin{array}{l}0.9 \\
0.5\end{array}$ \\
\hline $\begin{array}{c}\text { (Carrillo and Benitez, } \\
\text { 1994) }\end{array}$ & $300 \mathrm{mg}$ & 107 & 24 & 1.31 & 0.04 \\
\hline
\end{tabular}

3,7-dimethyluric acid

\begin{tabular}{|c|c|c|c|c|c|}
\hline References & Dose & Subjects treated & Duration (h) & $\begin{array}{l}\text { 3,7-dimethyluric } \\
\text { acid excretion (\%) }\end{array}$ & SD \\
\hline $\begin{array}{c}\text { (Dan-Shya et al., } \\
1983)\end{array}$ & $\begin{array}{l}\text { Theophylline }(7.5 \mathrm{mg} / \mathrm{kg}) \text { and } \\
\text { caffeine }(7.5 \mathrm{mg} / \mathrm{kg}) 2 \text { weeks later }\end{array}$ & 6 & 60 & 1.2 & 0.5 \\
\hline $\begin{array}{c}\text { (Carrillo and Benitez, } \\
\text { 1994) }\end{array}$ & $300 \mathrm{mg}$ & 98 & 24 & 0.16 & 0.13 \\
\hline
\end{tabular}

\section{3-methylxanthine}

\begin{tabular}{|c|c|c|c|c|}
\hline References & Dose & Subjects treated & $\begin{array}{c}\text { 3-methylxanthine } \\
\text { excretion (\%) }\end{array}$ & Duration (h) \\
\hline (Latini et al., 1981) & $5 \mathrm{mg} / \mathrm{kg}$ & 4 & 72 \\
\hline
\end{tabular}




\begin{tabular}{|c|c|c|c|c|c|}
\hline $\begin{array}{c}\text { (Dan-Shya et al., } \\
\text { 1983) }\end{array}$ & $\begin{array}{l}\text { Theophylline }(7.5 \mathrm{mg} / \mathrm{kg}) \text { and } \\
\text { caffeine }(7.5 \mathrm{mg} / \mathrm{kg}) 2 \text { weeks later }\end{array}$ & 6 & 60 & 2.3 & 0.3 \\
\hline $\begin{array}{l}\text { (Callahan et al., } \\
\text { 1982) }\end{array}$ & $5 \mathrm{mg} / \mathrm{kg}\left({ }^{14} \mathrm{C}\right.$-labeled caffeine) & 10 & 48 & $\begin{array}{l}2.09 \\
1.98 \\
2.12\end{array}$ & $\begin{array}{l}0.56 \\
0.24 \\
0.51\end{array}$ \\
\hline (Grant et al., 1983) & $300 \mathrm{mg}$ & 68 & 24 & 1.5 & 0.7 \\
\hline $\begin{array}{c}\text { (Blanchard et al., } \\
\text { 1985) }\end{array}$ & $5 \mathrm{mg} / \mathrm{kg}$ & $\begin{array}{l}5 \text { (elderly) } \\
7 \text { (young) }\end{array}$ & 24 & $\begin{array}{l}0.94 \\
1.93\end{array}$ & $\begin{array}{l}0.51 \\
0.91\end{array}$ \\
\hline (Scott et al., 1986) & $\begin{array}{l}123-369 \mathrm{mg} \\
300-750 \mathrm{mg}\end{array}$ & $\begin{array}{l}15 \text { pregnant } \\
9 \text { female }\end{array}$ & 24 & $\begin{array}{l}5.6 \\
2.6\end{array}$ & $\begin{array}{l}3.2 \\
0.7\end{array}$ \\
\hline $\begin{array}{c}\text { (Carrillo and Benitez, } \\
\text { 1994) }\end{array}$ & $300 \mathrm{mg}$ & 107 & 24 & 1.7 & 0.11 \\
\hline
\end{tabular}


Table S2. Main characteristics of the wastewater treatment plants (WWTPs) investigated

\begin{tabular}{|lccc|}
\hline \multicolumn{1}{|c}{$\begin{array}{c}\text { WWTPs investigated } \\
\text { (country) }\end{array}$} & $\begin{array}{c}\text { Mean daily flow rate } \\
\text { ( } \mathbf{m}^{\mathbf{3}} \text { /day) }\end{array}$ & Population served by WWTP & Sampling dates (2015) \\
\hline Bristol (UK) & 209,289 & 886,650 & $10-16$ March \\
Brussels (Belgium) & 251,830 & 954,000 & $18-24$ March \\
Castellón (Spain) & 42,372 & 180,000 & $25-31$ March \\
Copenhagen (Denmark) & 144,558 & 530,000 & $10-16$ March \\
Lugano (Switzerland) & 44,386 & 103,560 & $25-31$ March \\
Milan (Italy) & 437,726 & $1,100,000$ & $10-16$ March \\
Oslo (Norway) & 276,235 & 580,000 & $11-17$ March \\
Porto (Portugal) & 31,560 & 150,000 & $23-29$ April \\
Utrecht (The Netherlands) & 46,743 & 300,000 & $4-10$ March \\
Zurich (Switzerland) & 180,088 & 410,000 & $18-24$ March \\
\hline
\end{tabular}


Table S3. Precursor and products ions of the analyzed compounds with the associated collision energies

\begin{tabular}{|lccc|}
\hline Compound & $\begin{array}{c}\text { Precursor ion } \\
(\mathbf{m} / \mathbf{z})\end{array}$ & $\begin{array}{c}\text { Product ion } \mathbf{1}(\mathbf{m} / \mathbf{z}) \text { and } \\
\text { collision energy }(\mathrm{eV})\end{array}$ & $\begin{array}{c}\text { Product ion 2 }(\mathbf{m} / \mathbf{z}) \text { and } \\
\text { collision energy }(\mathrm{eV})\end{array}$ \\
\hline caffeine & 195.1 & $138(25)$ & $110(30)$ \\
caffeine- ${ }_{3} C^{13}$ & 198.1 & $140(25)$ & - \\
Paraxanthine (1,7-dimethylxanthine) & 181.1 & $124(26)$ & $96(32)$ \\
1-methylxanthine & 167.1 & $110(25)$ & $82(33)$ \\
7-methylxanthine & 167.1 & $124(24)$ & $150(24)$ \\
1-methyluric acid & 182.1 & $70.1(30)$ & $126.0(24)$ \\
1,7-dimethyluric acid & 197.1 & $140.1(25)$ & $69.1(35)$ \\
1,7-dimethyluric acid-d ${ }_{3}$ & 200.1 & $140.1(25)$ & - \\
\hline
\end{tabular}


Table S4. Linearities, recoveries, repeatability and quantification limits

\begin{tabular}{|c|c|c|c|c|c|}
\hline Compound & $\begin{array}{c}\text { Linearity } \\
\text { range }(\mathrm{ng} / \mathrm{mL})\end{array}$ & $\begin{array}{l}\text { Coefficient of } \\
\text { correlation }\left(r^{2}\right)\end{array}$ & $\begin{array}{c}\text { Recovery } \\
\text { (\%) }\end{array}$ & $\begin{array}{c}\text { Repeatability } \\
\text { RSD (\%) }\end{array}$ & $\begin{array}{l}\text { MQL } \\
(\mathrm{ng} / \mathrm{L})\end{array}$ \\
\hline Caffeine* & $0-600$ & 0.9989 & 88 & 12 & 3.6 \\
\hline Paraxanthine (1,7-dimethylxanthine)* & $0-600$ & 0.9996 & 76 & 5 & 6.6 \\
\hline 1-methylxanthine* & $0-600$ & 0.9996 & 72 & 14 & 6.1 \\
\hline 7-methylxanthine* & $0-600$ & 0.9999 & 64 & 10 & 28.5 \\
\hline 1-methyluric acid & $0-600$ & 0.9988 & 68 & 14 & 220 \\
\hline 1,7-dimethyluric acid & $0-600$ & 0.9990 & 87 & 4 & 185 \\
\hline
\end{tabular}

*(Senta et al., 2015) 


\section{REFERENCES}

Blanchard, J., Sawers, S., Jonkman, J., Tang-Liu, D., 1985. Comparison of the urinary metabolite profile of caffeine in young and elderly males. Br. J. Clin.

Pharmacol. 19, 225-232. doi:10.1111/j.1365-2125.1985.tb02635.x

Callahan, M.M., Robertson, R.S., Branfman, a. R., McComish, M.F., Yesair, D.W., 1983. Comparison of caffeine metabolism in three nonsmoking populations after oral administration of radiolabeled caffeine. Drug Metab. Dispos. 11, 211-217.

Callahan, M.M., Robertson, R.S., M.J., A., Branfman, A.R., McComish, M.F., Yesair, D.W., 1982. Human metabolism of [1-methyl-14C]- and [2-14C]caffeine after oral administration. Drug Metab. Dispos. 10, 417-423.

Carrillo, J.A., Benitez, J., 1994. Caffeine metabolism in a healthy Spanish population: N-Acetylator phenotype and oxidation pathways. Clin. Pharmacol. Ther. 293-304.

Dan-Shya, D., Tang-Liu, D., Williams, R., Riegelman, S., 1983. Disposition of caffeine and its metabolites in man. J. Pharmacol. Exp. Ther. 224, 180-185.

Grant, D.M., Tang, B.K., Kalow, W., 1983. Variability in caffeine metabolism. Clin. Pharmacol. Ther. 33, 591-602. doi:10.1038/clpt.1983.80

Latini, R., Bonati, M., Marzi, E., Garattini, S., 1981. Urinary excretion of an uracilic metabolite from caffeine y rat, monkey and man. Toxicol. Lett. 7, $267-272$.

Scott, N.R., Chakraborty, J., Marks, V., 1986. Urinary metabolites of caffeine in pregnant women. Br. J. Clin. Pharmacol. 22, $475-778$.

Senta, I., Gracia-Lor, E., Borsotti, A., Zuccato, E., Castiglioni, S., 2015. Wastewater analysis to monitor use of caffeine and nicotine and evaluation of their metabolites as biomarkers for population size assessment. Water Res. 74, 23-33. doi:10.1016/j.watres.2015.02.002 